\title{
Condition of urogenital tract microbiotes and pro- and antioxidant system in male azoospermia
}

\author{
M. Z. Vorobets, O. V. Melnyk, I. V. Kovalenko, R. V. Fafula, A. T. Borzhievsky, Z. D. Vorobets \\ Danylo Halytskyi Lviv National Medical University, Lviv, Ukraine
}

Article info

Received 07.10.2021

Received in revised form

02.11 .2021

Accepted 03.11.2021

Danylo Halytskyi

Lviv National Medical

University, Pekarska st., 69 ,

Lviv, 79010, Ukraine.

Tel.: +38-032-275-49-66.

E-mail:kaf_medicalbiologı@a meguniv.lviv.ua

\begin{abstract}
Vorobets, M. Z., Melnyk, O. V., Kovalenko, I. V., Fafula, R. V., Borzhievsky, A. T., \& Vorobets, Z. D. (2021). Condition of urogenital tract microbiotes and pro- and antioxidant system in male azoospermia. Regulatory Mechanisms in Biosystems, 12(4), 696-701. doi:10.15421/022196
\end{abstract}

Over the past 20 years, there has been a clear trend to increase in the number of infertile men in Ukraine, their percentage reaches $50 \%$ in infertile couples. There is a significant percentage of male infertility caused by azoospermia - the lack of sperm in the ejaculate. In male infertility, azoospermia is found in $10-15 \%$ of patients, among other forms of pathospermia. Given the ambiguity of ideas about the etiology, pathogenesis and treatment and diagnostic approaches for various types of infertility, it remains important to clarify the relationship of urogenital infections with the regulatory systems of cells, including the state of the pro- and antioxidant system and the search for additional markers. 119 patients with various forms of azoospermia were examined. All patients underwent the following studies: spermogram, infectious screening, inhibin B, lipid peroxidation, activity of enzymes of the glutathione antioxidant system in sperm plasma and blood serum. Infectious screening included analysis of urethral secretions, bacteriological examination of sperm or prostate secretion, assessment of the species and quantitative composition of the microflora of the male urogenital tract. According to the results of spermogram and other diagnostic methods, a non-obstructive form of azoospermia was detected in 69 patients. In obstructive azoospermia, ejaculate as such was absent. It is suggested that inhibin B may be an important medical diagnostic test for azoospermia. As a result of the conducted researches the importance of determining the concentration of inhibin $\mathrm{B}$ as a marker of azoospermia was demonstrated and a negative correlation of moderate strength between the content of inhibin B and testosterone level in the plasma of men with nonobstructive azoospermia was revealed. It was found that Ureaplasma pervum and Ureaplasma urealyticum infect the male genitourinary system to the greatest extent among a number of microorganisms, both in non-obstructive and obstructive forms of azoospermia. Enterococcus faecalis is more pronounced in the sperm fluid in the non-obstructive form of azoospermia and prostate secreton in the obstructive form of azoospermia. In the non-obstructive form of azoospermia in the seminal plasma and serum, the processes of lipid peroxidation intensify, the concentration of reduced glutathione decreases and the activities of the enzymes of the glutathione antioxidant system (glutathione peroxidase and glutathione transferase) decrease. It can be considered that an important diagnostic test for the nonobstructive form of azoospermia is the ratio of reduced glutathione to oxidized glutathione in sperm plasma.

Keywords: infertility; azoospermia; infections; semen plasma; lipid peroxidation; antioxidant enzymes.

\section{Introduction}

In recent decades, infertility has remained one of the leading problems in modern in medicine and has acquired medical and social significance (Zhou et al., 2013; Horpynchenko \& Romaniuk, 2016; Rogozin, 2020). This is due to the increasing incidence of infertility in marriages, which leads to lower birth rates and lower populations. In European countries, about $15 \%$ of couples turn to reproductive therapists with infertility issues (Kherraf et al., 2017). Thus, according to the WHO, the prevalence of infertility has increased by $50 \%$ over the past two decades, and the percentage of male-related infertility ranges from $20 \%$ to $70 \%$ (Horpynchenko \& Romaniuk, 2016; Kulchenko \& Demiashkin, 2016; Kherraf et al., 2017). Over the past 20 years, there has been a clear trend to increase in the number of infertile men in Ukraine, their percentage reaches $50 \%$ in infertile couples (Horpynchenko \& Romaniuk, 2016; Kulchenko \& Demiashkin, 2016; Fafula et al., 2019). Male reproductive potential is mainly reduced due to such factors as urinary tract infections, genetic disorders, malignant neoplasms, endocrinopathies, immunological factors. However, in most cases, male infertility is associated with a decrease in the number and quality of sperm. However, there is a significant percentage of male infertility caused by azoospermia - the lack of sperm in the ejaculate. This is the most difficult form of male infertility to treat (Gamidov et al., 2015). Depending on the causes and nature of the violation of spermatogenesis, most researchers have recently divided azoospermia into obstructive (excretory) and non-obstructive (secretory) (Jungwirth et al., 2015). In male infertility, azoospermia is found in $10-15 \%$ of patients, among other pathospermia. The proportion of obstructive and nonobstructive forms is approximately $40 \%$ and $60 \%$, respectively. According to other data, the non-obstructive form of azoospermia (NOA) is the dominant form of pathology and occurs in $80-90 \%$ of all cases of azoospermia (Bostwick \& Cheng, 2014). There is also evidence that according to the results of biopsies, the structure of azoospermia forms is as follows: obstructive $-55 \%$, non-obstructive $-45 \%$. The main causes of obstructive azoospermia are infectious and inflammatory diseases, post-operative and post-traumatic disorders, congenital anomalies of the vas deferens and cysts of the epididymis. Causes of nonobstructive azoospermia are secondary hypergonadotropic hypogonadism, consequences of untreated varicocele, primary hypogonadism, chromosomal deletions and translocations, Klinefelter's syndrome (Fu, 2012; Li et al., 2018; Vorobets et al., 2020).

Undoubtedly, urogenital infections play an important role in this (Enwuru \& Iwalokun, 2016; Grande, 2018; Al-Jebouri \& Mohamed, 2021). The structure of pathogens of infectious diseases has undergone significant evolution in recent years. Microorganisms that cause inflam- 
matory diseases of the genitourinary system are no exception. The number of patients with varying degrees of male fertility disorders is constantly increasing due to the direct or indirect action of various microorganisms. Clinical experience shows that in most cases, latent and chronic forms of urogenital infections predominate, which greatly complicates timely diagnosis. Such forms of infectious diseases are difficult to diagnose because their clinical symptoms are erased or absent. Therefore, patients rarely seek treatment. The pathology progresses and is often complicated by the development of infertility. There are several potentially open questions about the validity of a significant increase in cases of male infertility, caused for the first time by opportunistic pathogens of individual members or their associations. The etiological structure of inflammatory diseases of the genitourinary system is dynamic: the causative agents of these processes differ depending on various factors. It should be noted that microbial virulence factors and the degree of colonization play an important role in the development of the infectious process. In some cases, it can cause inflammation of the genitourinary system, and in others it can maintain inflammation of the urogenital tract, initiated by other factors. The inflammatory process is often accompanied by an increase in the number of immunocompetent cells, neutrophils, inflammatory mediators that produce free radicals and reactive oxygen species. However, in the literature there is insufficient data on the pathogenesis of various forms of pathospermia, and hence the possibility of normalization of spermatogenesis (Faniev et al., 2017; Marchiani et al., 2021). Currently, to assess the state of spermatogenesis using a spermogram and determine the concentration of follicle-stimulating hormone (FSH) in blood plasma, in some cases, a testicular biopsy is performed to determine the cause of spermatogenesis: testicular or obstructive pathology. Given the ambiguity of ideas about the etiology, pathogenesis and treatment and diagnostic approaches for various types of infertility, it remains important to clarify the relationship of urogenital infections with the regulatory systems of cells, including the state of the pro- and antioxidant system and the search for additional markers.

\section{Materials and methods}

The material for the implementation of the tasks were the results of examination of patients with infertility, who were under observation at the Department of Urology of Danylo Halytsky Lviv National Medical University and Regional Consultative Polyclinic of the Lviv Regional Clinical Hospital. 119 patients with various forms of azoospermia were examined. The age of patients who underwent clinical diagnostic, microbiological and biochemical bioassays varied from 22 to 48 years. The average age of patients with testicular (secretory) infertility was 28.6 years, and with posttesticular (excretory-obstructive) - 31.5 years. The average term of infertility was 4.2 years. Among 119 examined patients with azoospermia, $69(58.0 \%)$ were diagnosed with secretory infertility. In 50 (42.0\%) patients, preserved spermatogenesis with excretory-obstructive infertility was noted. Patients with a mixed form of azoospermia were not considered in the studies. The control group consisted of 46 healthy men with normozoospermia aged 22 to 45 years (mean age $32.7 \pm 4.3$ years) and $49 \%$ of them had children. They underwent a spermogram, as well as sonoelastographic and biochemical studies of ejaculate and serum. Examination of patients began with the collection of complaints, history and palpation of the scrotum and spermatic cord. Ultrasound with Doppler effect and high-quality compression elastography of the scrotum was performed as a comprehensive sonological examination. Inclusion and exclusion criteria were taken into account in the selection of study groups.

Inclusion criteria: reproductive age of patients (22-48 years), established fact of infertility, absence of female infertility factor in marriage, lack of hormonal correction of infertility. Exclusion criteria: age $<22$ years and $>48$ years, severe general systemic diseases, diseases that require drugs that can affect spermatogenesis, in particular hormonal drugs, varicocele, the presence of sperm in the ejaculate, the presence of a history of previous testicular biopsy. Criteria for azoospermia are the absence of sperm in an ejaculate or the absence of ejaculate. Criteria for the obstructive form of azoospermia - the absence of sperm in an ejaculate with preserved spermatogenesis. Criteria for non-obstructive azoospermia - the absence of sperm in the ejaculate due to a violation of the spermatogene- sis. Diagnosis of infertility, as well as other diseases, is based on patient complaints, history, objective status and the results of special research methods.

All the men were made aware of patient information leaflets and gave informed consent to participate in the study. Terms of sample selection meet the requirements of the principles of Convention of Europe Council on Human Rights, Helsinki Declaration on Protection of Human Rights and Biomedicine and the laws of Ukraine. Approval for study was taken from the ethics committe of Danylo Halytsky Lviv National Medical University.

It is known that men with infertility, especially with azoospermia, belong to a complex category of patients, due to the difficulty of diagnosing the causes and degree of impaired spermatogenesis, as well as the choice of treatment methods. All patients underwent the following studies: spermogram, infectious screening, inhibin B, lipid peroxidation, activity of enzymes of the glutathione antioxidant system in sperm plasma and serum. Infectious screening included analysis of urethral secretions, bacteriological examination of sperm or prostate secretion, assessment of the species and quantitative composition of the microflora of the male urogenital tract. PCR diagnosis of sexually transmitted infections and invasions was performed using a set of reagents "DNA technology" on an automatic fluorescent analyzer. The titer of opportunistic pathogens was quantified, the indicator $>10^{4} \mathrm{CFU} / \mathrm{mL}$ was considered diagnostically significant. In accordance with the WHO recommendations (2010), microbiological studies of ejaculate were performed when the threshold values of leukocytes in the seminal plasma exceeded $10^{6}$ cells $/ \mathrm{mL}$ (WHO laboratory manual for the examination and processing of human semen, 2010). Ejaculate was collected in sterile tubes and inoculated with 5\% blood agar and Saburo agar. Evaluation of the results of the study included quantitative accounting (titer) -determination of the number of colony-forming units per $1 \mathrm{~mL}(\mathrm{CFU} / \mathrm{mL})$ and species affiliation of all significant phenotypes. The research was conducted on the basis of the Urology Department of the Lviv Regional Clinical Hospital and Synevo Laboratory. Lipid peroxidation was determined by the content of malonic aldehyde (Sinha \& Gupta, 2018). Determination of malone malondialdehyde (MDA) content is based on its interaction with 2-thiobarbituric acid (TBA) with the formation of chromogen with a maximum absorption in the red spectrum at a wavelength of $532 \mathrm{~nm}$. The state of the antioxidant system was inferred from the concentration of reduced glutathione (Naher \& Biswas, 2011), glutathione peroxidase, glutathione reductase and glutathione S-transferase (Fafula et al, 2019). The protein content in the lymphocyte mixture was determined by a modified Lowry method using a kit to determine its concentration (Simko Ltd.).

Mathematical analysis of the research results was carried out using software pack Statistica 10.0 (StatSoft Inc., USA). The results are presented as the mean \pm standard error $(x \pm S E)$. Analysis of variance (ANOVA) was used to compare the difference in the means between studied groups. Differences were considered statistically significant at $\mathrm{P}<$ 0.05 for all analyses.

\section{Results}

According to the results of spermogram and other diagnostic methods, a non-obstructive form of azoospermia (NOA) was detected in 69 patients. The anamnesis of the patients' life was not burdened, the absence of injuries, epidemic mumps, surgical interventions on genitals was proved. Ultrasound examination of the scrotum revealed no structural pathology. The veins of the right and left spermatic cord were $2 \mathrm{~mm}$ in diameter, with no signs of impaired blood flow. Each patient with NOA donated semen twice with an interval of two weeks. On the basis of examination and conclusion of spermograms all patients in the experimental group were found to have a complete absence of sperm in the ejaculate, which indicates the presence of a non-obstructive form of azoospermia (Table 1). In obstructive azoospermia (OA), ejaculate as such was absent.

It is suggested that inhibin B may be an important medical diagnostic test for azoospermia. In our studies of normozoospermia $(n=46)$, the level of inhibin $\mathrm{B}$ in the serum was $217.3 \pm 50.8 \mathrm{pg} / \mathrm{mL}$. At NOA $(\mathrm{n}=69)$ the level of inhibin B was 2.7 times lower than normal and was $59.8 \pm$ $19.6 \mathrm{pg} / \mathrm{mL}$ (Fig. 1). 
The correlation screening revealed that the content of inhibin $\mathrm{B}$ among the various parameters of sex hormones is most closely correlated with the concentration of testosterone (Table 2). There is a probable negative correlation of medium strength.

\section{Table 1}

Spermogram results of patients

with non-obstructive azoospermia $(\mathrm{x} \pm \mathrm{SE}, \mathrm{n}=69)$

\begin{tabular}{lc}
\hline \multicolumn{1}{c}{ Indicators } & Value \\
\hline Ejaculate volume, $\mathrm{mL}$ & $\leq 1.5$ \\
$\mathrm{pH}$ & $7.2 \pm 0.5$ \\
Total sperm count, $\mathrm{mln}$ & not found \\
Sperm concentration, $\mathrm{mln} / \mathrm{mL}$ & not found \\
Total sperm motility, $\%$ & not found \\
Sperm with progressive movement, $\%$ & not found \\
The number of pathological forms, $\%$ & not found \\
Leukocyte concentration, cells $/ \mathrm{mL}$ & $\leq 10^{6}$ \\
\hline
\end{tabular}

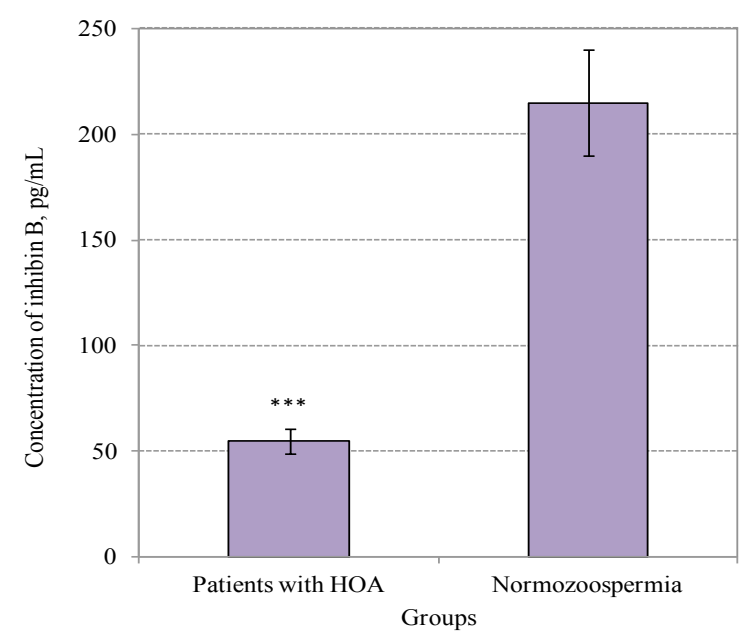

Fig. 1. Content of inhibin $B$ in non-obstructive form of azoospermia $(\mathrm{x} \pm \mathrm{SE}, \mathrm{n}=69)$ : ***-P<0.001 compared to the values in the control group (normozoospermia)

Table 2

Correlation coefficients of a linear relationship between the concentration of inhibin $\mathrm{B}$, sex hormones and other indicators in patients with azoospermia $(n=69)$

\begin{tabular}{lc}
\hline \multicolumn{1}{c}{ Indicators } & Inhibin B \\
\hline Follicle-stimulating hormone & $0.214 \pm 0.117$ \\
Luteinizing hormone & $-0.162 \pm 0.119$ \\
Prolactin & $-0.524 \pm 0.102^{* * *}$ \\
Testosterone & $-0.720 \pm 0.083^{* * *}$ \\
Estradiol & $0.124 \pm 0.119$ \\
The size of the testicles & $0.725 \pm 0.082^{* * *}$ \\
Linear blood flow velocity & $0.245 \pm 0.116^{*}$ \\
\hline
\end{tabular}

Note: ${ }^{*}-\mathrm{P}<0.05, * *-\mathrm{P}<0.01, * * *-\mathrm{P}<0.001$.

However, significant negative correlations of medium strength were found between the concentration of prolactin and the content of inhibin B. Among the instrumental parameters, a significant positive correlation was found between the testicular size of azoospermic men and the content of inhibin B. As a result of the correlation analysis, a negative correlation of moderate strength $(r=-0.72)$ was found between the content of inhibin and testosterone in the blood plasma of men with NOA (Fig. 2).

A number of data indicate the important role of infectious factors in the development of azoospermia. Studying the presence of invasive and infectious factors in the urethra by PCR, it was found that the number of men with a history of Trichomonas infection in NOA was $1.6 \%$ and in $\mathrm{OA}-1.5 \%$ (Fig. 3 ).

The detection rate of Chlamydia trachomatis by PCR in NOA was $3.3 \%$ and in $\mathrm{OA}-2.9 \%$. Mycoplasma genitalium in NOA was detected in $5.7 \%$ and in $\mathrm{OA}$ - in $2.9 \%$. Ureaplasma urealyticum was diagnosed in $12.3 \%$ with NOA and $11.7 \%$ with OA, and U. parvum in $13.1 \%$ with NOA and $19.1 \%$ with OA. In NOA Neisseria gonorrhoeae was detected in $6.6 \%$, and in $\mathrm{OA}-$ in $13.2 \%$. Herpes simplex virus type 2 was observed in $5.7 \%$ of men with NOA and in $7.3 \%$ of men with OA. Gardnerella vaginalis was diagnosed in $9.0 \%$ of men with NOA and in $13.3 \%$ of men with OA.

Bacteriological culture revealed that the species spectrum of opportunistic microflora in the ejaculate or prostate secretion of men with azoospermia in diagnostically significant titers was diverse, but with low rates (Fig. 4).

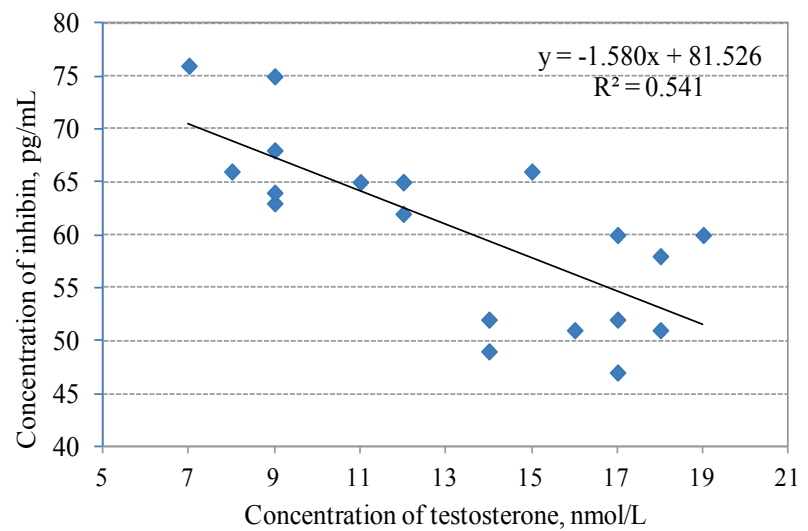

Fig. 2. Correlation relationship between concentrations of inhibin B and testosterone level in patients with non-obstructive form of azoospermia $(n=20)$

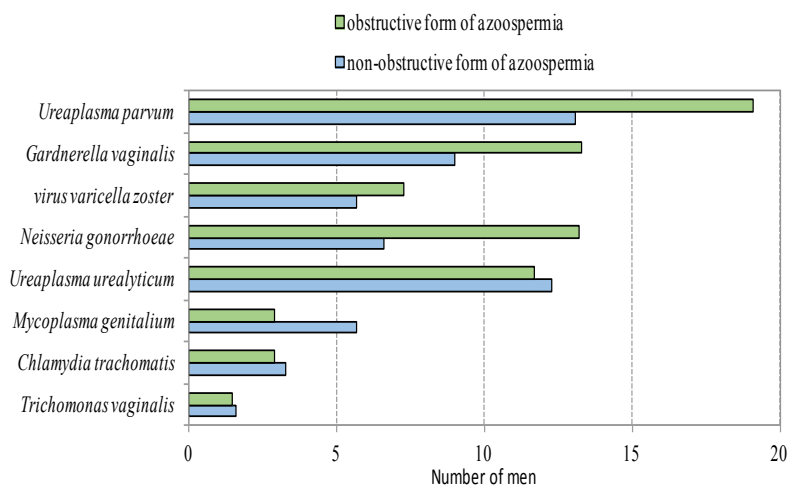

Fig. 3. Sexually transmitted infections in men with azoospermia $(n=119)$

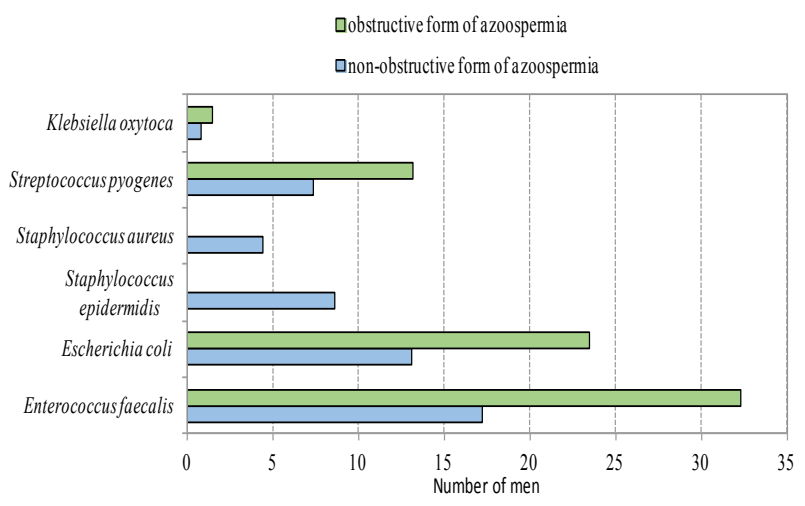

Fig. 4. Bacteriological examination of ejaculate/prostate secretion in men with azoospermia $(\mathrm{n}=119)$

The frequency of detection of Enterococcus faecalis in men with azoospermia in OA was $32.3 \%$, which is almost twice as high as in NOA (17.2\%). Infection of ejaculate/prostate secretion with Escherichia coli in NOA was detected in $13.1 \%$, and in OA - in $23.5 \%$. Staphylococcus aureus was detected only in OA (4.4\%). Streptococcus pyogenes was detected in both NOA (7.4\%) and OA (13.2\%). Staphylococcus epidermidis was detected only in OA $-4.4 \%$. Klebsiella oxytoca was detected in $0.8 \%$ of patients with NOSA and $1.5 \%$ of patients with OA.

The correspondence of bacteriospermia to the data of clinical examination of men with a history of chronic inflammatory diseases of the ge- 
nital organs is noteworthy. As the data of Figure 4, microbial contamination of ejaculate and prostate secretion samples was predominant in men with OA $(79.3 \%)$ versus $38.5 \%$ in men with NOA. Since bacterial contamination of the genitourinary tract or sperm can cause oxidative stress, we studied the processes of lipid peroxidation and glutathione systems in the seminal plasma of men diagnosed with nonobstructive azoospermia (Table 3). The activation of lipid peroxidation processes by determining the concentration of malonic dialdehyde is shown. The concentration of MDA as a biomarker of lipid peroxidation in seminal plasma in control was $2.3 \pm 0.3 \mu \mathrm{mol} / \mathrm{L}$ and in nonobstructive form of azoospermia $-3.7 \pm$ $0.3 \mu \mathrm{mol} / \mathrm{L}$, ie increased by 1.61 times $(\mathrm{P}<0.01)$. Simultaneously with the activation of lipid peroxidation, a significant decrease in glutathione peroxidase activity relative to control values was detected. Enzyme activity decreased by 1.29 times - from $18.3 \pm 2.1 \mathrm{nmol} \mathrm{GSH} / \mathrm{min} \cdot \mathrm{mg}$ protein (normozoospermia) to $14.1 \pm 1.6 \mathrm{nmol} \mathrm{GSH} / \mathrm{min} \cdot \mathrm{mg}$ protein (patients with NOA, $\mathrm{P}<0.05$ ). Regarding the activity of glutathione reductase, in patients with NOA it was 1.33 lower than in control group (normozoospermia), but these changes are not significant. In the study of glutathione transferase activity, it was found that it was normally $3.41 \pm 0.38 \mathrm{nmol}$ $\mathrm{GSH} / \mathrm{min} \cdot \mathrm{mg}$ protein. In the non-obstructive form of azoospermia, the activity of glutathione transferase was significantly reduced by 1.21 times $(\mathrm{P}<0.05)$.

\section{Table 3}

The state of the glutathione antioxidant system and lipid peroxidation in the seminal plasma of men with nonobstructive azoospermia $(x \pm S E, n=69)$

\begin{tabular}{lcc}
\hline \multicolumn{1}{c}{ Indicators } & $\begin{array}{c}\text { Almost healthy men } \\
\text { (normozoospermia) } \\
\mathrm{n}=46\end{array}$ & $\begin{array}{c}\text { Non-obstructive form } \\
\text { of azoospermia } \\
\mathrm{n}=69\end{array}$ \\
\hline $\mathrm{MDA}, \mu \mathrm{mol} / \mathrm{L}$ & $2.34 \pm 0.32$ & $3.72 \pm 0.36^{* *}$ \\
$\mathrm{GP}, \mathrm{nmol} \mathrm{GSH} / \mathrm{min} \cdot \mathrm{mg}$ protein & $18.36 \pm 1.53$ & $14.12 \pm 1.41^{*}$ \\
$\mathrm{GR}, \mathrm{nmol} \mathrm{NADPH} / \mathrm{min} \cdot \mathrm{mg}$ protein & $0.320 \pm 0.052$ & $0.248 \pm 0.040$ \\
$\mathrm{GT}, \mathrm{nmol} \mathrm{GSH} / \mathrm{min} \cdot \mathrm{mg}$ protein & $3.41 \pm 0.23$ & $2.81 \pm 0.18^{*}$ \\
\hline
\end{tabular}

Note: $*_{-} \mathrm{P}<0.05, * *-\mathrm{P}<0.01,{ }^{* * *}-\mathrm{P}<0.001$ compared to the values in the control group (normozoospermia).

The state of the non-enzymatic component of the antioxidant system in seminal plasma was assessed by the content of reduced, total and oxidized glutathione and the redox index of glutathione calculated by the ratio of the difference between the content of total and oxidized glutathione to total glutathione (Table 4)

Table 4

Indicators of pro- and antioxidant system

in seminal plasma of men with azoospermia $(x \pm S E, n=69)$

\begin{tabular}{lcc}
\hline \multicolumn{1}{c}{ Indicators } & $\begin{array}{c}\text { Almost healthy men } \\
\text { (normozoospermia, } \\
\mathrm{n}=46)\end{array}$ & $\begin{array}{c}\text { Non-obstructive } \\
\text { form of azoospermia } \\
(\mathrm{n}=69)\end{array}$ \\
\hline Total antioxidant activity, $\mu \mathrm{mol} / \mathrm{L}$ & $2.11 \pm 0.16$ & $1.41 \pm 0.12^{* * *}$ \\
$\mathrm{GSH}, \mu \mathrm{mol} / \mathrm{L}$ & $34.32 \pm 2.85$ & $19.35 \pm 1.52^{* * *}$ \\
$\mathrm{GSH}, \mu \mathrm{mol} / \mathrm{L}$ & $57.35 \pm 4.95$ & $38.45 \pm 3.47^{* *}$ \\
$\mathrm{GSSG}, \mu \mathrm{mol} / \mathrm{L}$ & $22.85 \pm 2.25$ & $21.26 \pm 2.02$ \\
$\mathrm{GSH} / \mathrm{GSSG}$ & $1.50 \pm 0.22$ & $0.91 \pm 0.14^{*}$ \\
$\mathrm{RIGSH}$ & $0.601 \pm 0.052$ & $0.447 \pm 0.049^{*}$ \\
\hline
\end{tabular}

Note: $*-\mathrm{P}<0.05, * *-\mathrm{P}<0.01, * * *-\mathrm{P}<0.001$ compared to the values in the control group; RI GSH - redox index of glutathione.

The total antioxidant activity in patients with NOA was reduced by 1.49 times $(\mathrm{P}<0.001)$. The concentration of reduced glutathione decreased by 1.8 times and the concentration of total glutathione decreased by 1.77 times $(\mathrm{P}<0.01)$. No significant changes in the concentration of oxidized glutathione were detected. It can be considered that an important diagnostic test for NOA is the ratio of reduced glutathione to oxidized glutathione in sperm plasma: in normozoospermia $-1.50 \pm 0.22$ and in $\mathrm{NOA}-0.91 \pm 0.14(\mathrm{P}<0.01)$.

In the study of individual non-ezymatic components of the glutathione antioxidant system in blood serum, it was found that the total antioxidant activity in NOA was reduced by 1.22 times, but these changes are not significant (Table 5). The concentration of reduced glutathione decreased by 1.59 times $(\mathrm{P}<0.001)$, and the concentration of total glutathione de- creased by 1.22 times, but these changes are not significant. As in the case of seminal plasma, no significant changes in the concentration of oxidized glutathione were detected. The calculation of the redox index (RI GSH) showed a 1.33 -fold decrease $(\mathrm{P}<0.05)$ in the total power of this system in the seminal plasma of men with non-obstructive azoospermia. No such decrease is observed in the serum. However, a sharp decrease in the concentration of reduced glutathione and its ratio to oxidized glutathione in the serum indicates its increased use in both seminal plasma and blood.

\section{Table 5}

Indicators of pro- and antioxidant system in blood serum $(\mathrm{x} \pm \mathrm{SE}, \mathrm{n}=69)$

\begin{tabular}{lcc}
\hline \multicolumn{1}{c}{ Indicators } & $\begin{array}{c}\text { Almost healthy men } \\
\text { (normozoospermia, } \\
\mathrm{n}=46)\end{array}$ & $\begin{array}{c}\text { Non-obstructive form } \\
\text { of azoospermia } \\
(\mathrm{n}=69)\end{array}$ \\
\hline $\mathrm{MDA}, \mu \mathrm{mol} / \mathrm{L}$ & $31.14 \pm 3.35$ & $42.44 \pm 4.30$ \\
Total antioxidant activity, $\mu \mathrm{mol} / \mathrm{L}$ & $1.225 \pm 0.144$ & $0.980 \pm 0.122$ \\
$\mathrm{GSH}, \mu \mathrm{mol} / \mathrm{L}$ & $17.82 \pm 1.18$ & $11.20 \pm 1.15^{* * *}$ \\
$\mathrm{GSHt}, \mu \mathrm{mol} / \mathrm{L}$ & $19.64 \pm 1.84$ & $16.14 \pm 1.52$ \\
$\mathrm{GSSG}, \mu \mathrm{mol} / \mathrm{L}$ & $1.32 \pm 0.18$ & $1.42 \pm 0.24$ \\
GSH/GSSG & $13.48 \pm 0.36$ & $7.88 \pm 0.22$ \\
RI GSH & $0.932 \pm 0.120$ & $0.912 \pm 0.104$ \\
\hline
\end{tabular}

Note: see Table 4.

\section{Discussion}

When diagnosing male infertility, the basic study is a spermogram, although it does not provide an understanding of the causes of impaired spermatogenesis. One of the important markers and expert methods of diagnosis, which allows us to assess the morphofunctional state of the testicular parenchyma, may be the hormone inhibin $\mathrm{B}$, which is a universal growth factor belonging to the family of transforming growth factors $\beta$ (Hafez et al., 2014; Binder et al., 2015; Grunewald et al., 2015). This hormone is produced in the testes by Sertoli cells and is known to synchronize the work of the hypothalamic-pituitary-gonadal axis together with follicle-stimulating hormone (Meachem et al., 2001). The anterior pituitary gland regulates the reproductive system with the help of gonadotropic hormones - FSH and luteinizing hormone ( $\mathrm{LH})$. For $\mathrm{LH}$, the main target cells in men are Leydig cells, which secrete testosterone, the most important hormone for stimulating spermatogenesis in men.

It is known that the secretion of inhibin B directly depends on the level of FSH and spermatogenesis (Deng et al., 2014). A level of inhibin B less than $80 \mathrm{pkg} / \mathrm{mL}$ indicates the presence of reproductive problems in men. These data are directly correlated with testicular function. Inhibin B levels are higher in men who do not have fertility problems. In patients who have been castrated, inhibin B is not detected. This strongly confirms that inhibin B reflects the function of the testes, in particular Sertoli cells. There is a relationship between the level of inhibin B, the level of FSH and testicular function and the level of inhibin $B$ in the serum reflects the functional state of spermatogenesis, as it participates in the feedback of the hypothalamic-pituitary-testicular axis (Grunewald et al., 2015; Ibrahim et al., 2015). It is suggested that the assessment of serum inhibin B levels may be an alternative to biopsy and also used for the differential diagnosis of male infertility (Barbotin et al., 2015; Grunewal et al., 2015). Literature data show that in normozoospermia the level of inhibin B in the serum is $202 \pm$ $47 \mathrm{pg} / \mathrm{mL}$ and in azoospermia $-61 \pm 78 \mathrm{pg} / \mathrm{mL}$ (Kadyrov et al., 2015).

Literature data also show that the infectious-toxic factor in 8.5-36.0\% is the cause of male infertility (Horpynchenko et al., 2016; Horpynchenko \& Romniuk, 2016). It should be noted that according to the literature, chlamydia occurs in $45 \%$ of patients with NOA (Rogozin, 2020). However, whether chlamydial infection is the cause of azoospermia is debatable. There is evidence that urogenital infections can lead to unilateral or bilateral obstruction of the ejaculatory tract, as well as the appearance of antibodies to sperm and ejaculatory dysfunction (Kurylo et al., 2016). The most common urogenital infections are caused by microorganisms such as Chlamidia trachomatis, Mycoplasma hominis and Ureaplasma urealiticum, as well as gram-negative microflora and often asymptomatic, leading to pathozoospermia (Horpynchenko \& Romniuk, 2016; Chen et al., 2018). In addition, increased production of oxygen free radicals in inflammation can reduce the fertility of sperm due to damage to sperm mem- 
branes and their DNA (Aitken \& Koppers, 2011). It should be noted that the question of the role of subclinically and clinically pronounced infections of the male genital tract in the formation of infertility is still debated. Many different mechanisms are involved in the deterioration of spermatogenesis and sperm quality caused by infection of the gonads or inflammatory processes. Leukocytes are markers of infection, but there are controversial views on the effect of their presence in seminal plasma on male fertility. According to WHO recommendations, $10^{6}$ leukocytes $/ \mathrm{mL}$ of ejaculate should be considered as the limit of leukocytospermia. However, many studies have not found a correlation between the number of leukocytes and the number of sperm progenitor cells or their function (Havrylyuk et al., 2013).

The most common method of identifying a bacterial infection of the male urogenital tract is microbiological culture of seminal fluid or prostate secretion. If the number of pathogen colonies is large after classical culture, there is a version of probable damage to the spermatogenic epithelium or sperm by free oxygen radicals. The latter are always contained in excess in infected biological fluids because in the inflammatory process they migrate phagocytes with activated oxygen-dependent enzymes. However, the question of whether infectious factors are always the cause of azoospermia is not clear. It cannot be ruled out that this is just a combination of asymptomatic infection with another (underlying) pathology. It should be noted that the infection caused by Ureaplasma urealyticum is the most dangerous for the reproductive function of men (Rogozin, 2020). Our studies revealed the highest percentage of this pathogen among other microorganisms, with $\mathrm{NOA}-12.3 \%$, and with $\mathrm{OA}-11.7 \%$. This is the most common microorganism that infects the male reproductive system. This pathogen alters various characteristics of the process of spermatogenesis, in particular spermatogenic epithelium and sperm.

Thus, urogenital infections are an important reason for reduced male fertility. By damaging the spermatogenic epithelium, microorganisms cause disorders of spermatogenesis, the appearance of abnormal and pathological forms of sperm. Once in the ejaculate, infectious agents can disrupt sperm motility by producing reactive oxygen species, leading to peroxidation of membrane lipids, mitochondrial damage, and pro- / antioxidant imbalance (Horpynchenko \& Romniuk, 2016; Rogozin, 2020; Vorobets et al., 2020). According to modern ideas, the development of pathological processes in the body, in particular caused by microorganisms, is accompanied by a violation of the mechanisms of antioxidant protection of cells (Fafula et al., 2017; Aitken, 2020; Yin et al., 2020). The obtained data to some extent agree with others where the increase of MDA level and decrease of concentration of reduced glutathione in seminal plasma at azoospermia is shown (Krzysciak et al., 2020; Kurkowska et al., 2020). The obtained data are to some extent consistent with others where an increase in the MDA level and a decrease in the concentration of reduced glutathione in seminal plasma in azoospermia (N'Guessan at al., 2016; Fafula et al., 2017; Sinha \& Gupta, 2018) and impaired expression of the glutathione transferase gene family are associated with the development of male infertility (Fafula et al., 2019). In general, lipid peroxidation is thought to cause oxidative stress, which is one of the causes of infertility.

\section{Conclusion}

As a result of the conducted research the importance of determining the concentration of inhibin $\mathrm{B}$ as a marker of azoospermia was demonstrated and a negative correlation of moderate strength between the content of inhibin B and testosterone level in the plasma of men with nonobstructive azoospermia was revealed. It was found that Ureaplasma pervum and $U$. urealyticum infect the male genitourinary system to the greatest extent among a number of microorganisms, both in non-obstructive and obstructive forms of azoospermia. Enterococcus faecalis is more pronounced in the sperm fluid in the non-obstructive form of azoospermia and prostate secretion in the obstructive form of azoospermia. The processes of lipid peroxidation intensify, the concentration of reduced glutathione decreases, and the activities of the enzymes of the glutathione antioxidant system, glutathione peroxidase and glutathione transferase decrease in the seminal plasma and serum in the non-obstructive form of azoospermia. It can be considered that an important diagnostic test for the nonobstructive form of azoospermia is the ratio of reduced glutathione to oxidized glutathione in sperm plasma.

\section{References}

Aitken, R. J. (2020). Impact of oxidative stress on male and female germ cells: Implications for fertility. Reproduction, 159, 189-201.

Aitken, R., \& Koppers, A. (2011). Apoptosis and DNA damage in human spermatozoa. Asian Journal of Andrology, 13, 36-42.

Al-Jebouri, M., \& Mohamed, A. (2021). A study on infertility of males infected with mycoplasma hominis with reference to sperm morphology. Open Journal of Pathology, 11, 7-21.

Barati, E., Nikzad, H., \& Karimian, M. (2020). Oxidative stress and male infertility: Current knowledge of pathophysiology and role of antioxidant therapy in disease management. Cellular and Molecular Life Sciences, 77(1), 93-113.

Barbotin, A. L., Ballot, C., Sigala, J., Ramdane, M., Duhamel, A., Marcelli F., Rigot, J. M., Dewailly, D., Pigny, P., \& Mitchell, V. (2015). The serum inhibin B concentration and reference ranges in normozoospermia. European Journal of Endocrinology, 172(6), 669-676.

Binder, G., Schweizer, R., Blumenstock, G., \& Braun, R. (2015). Inhibin B plus LH vs GnRH agonist test for distinguishing constitutional delay of growth and puberty from isolated hypogonadotropic hypogonadism in boys. Clinical Endocrinology, 82(1), 100-105.

Bostwick, D. G., \& Cheng, L. (2014). Urologic surgical pathology. 3th edition. Elsevier, Mosby.

Chen, H., Luo, T., Chen, T., \& Wang, G. (2018). Seminal bacterial composition in patients with obstructive and non-obstructive azoospermia. Experimental and Therapeutic Medicine, 15(3), 2884-2890.

Deng, Y., Jing, F., Zhou, N., Hu, Y., Chen, J., \& Chu, Q. (2014). Combined evaluation of serum follicle-stimulating hormone, inhibin $\mathrm{B}$, chromosome karyotyping and AZF microdeletion of Y-chromosome for predicting outcomes of testicular sperm aspiration in azoospermic patients. Journal of Southern Medical University, 34(10), 1469-1474.

Enwurua, C. A., Iwalokuna, B., Enwuru, V. N., Ezechi, O., \& Oluwadun, A. (2016). The effect of presence of facultative bacteria species on semen and sperm quality of men seeking fertility care. African Journal of Urology, 22(3), 213-222.

Fafula, R. V., Paranyak, N. M., Besedina, A. S., Vorobets, D. Z., Iefremova, U. P. Onufrovych, O. K., \& Vorobets, Z. D. (2019). Biological significance of glutathione S-transferases in human sperm cells. Journal of Human Reproductive Sciences, 12(1), 24-28.

Fafula, R. V., Onufrovych, O. K., Iefremova, U. P., Nakonechnyi, I. A., \& Vorobets, Z. D. (2017). Intensyvnist' protsesiv lipoperoksydatsiyi u spermatozoyidakh cholovikiv iz porushennyam fertyl'nosti [Intensity of lipoperoxidation processes in sperm of men with impaired fertility]. Bulletin of Problems of Biology and Medicine, 135, 199-204 (in Ukrainian).

Fafula, R. V., Onufrovych, O. K., Vorobets, D. Z., Iefremova, U. P., \& Vorobets, Z. D. (2017). Glutathione antioxidant protection system in ejaculated spermatozoa of infertile men with different forms of pathospermia. Studia Biologica, 11(1), 17-24

Faniev, M. V., Shevchenko, N. P., \& Kadyrov, Z. A. (2017). Sovremennyye strategii vedeniya infertil'nykh muzhchin khronicheskim bacterial'nym prostatitom na etape pregravidarnoy podgotovki v protokole vspomogatel'nykh [Modern strategies for managing infertile men with chronic bacterial prostatitis at the stage of pregravid preparation in the protocol of assisted reproductive technologies]. Andrology and Genital Surgery, 18(3), 44-53 (in Russian).

Fu, L., Ding, X., Shen, M., Li, C., Nie, S., \& Quan, Q. (2012). Screening and clinical phenotype analysis of microdeletions of azoospermia factor region on $\mathrm{Y}$ chromosome in 1011 infertile men. Chinese Journal of Medical Genetics, 29(2), $184-187$.

Gamidov, S. I., Popova, A. Y., \& Ovchinnikov, R. I. (2015). Neobstruktivnaya azoospermiya - klinicheskiye rekomendatsii [Nonobstructive azoospermia - clinical recommendations]. Russian Medical Journal, 23(11), 595-601 (in Russian).

Grande, G., Vincenzoni, F., Mancini, F., Baroni, S., Luca, G., Calafiore, R., Marana, R., Castagnola, M., Pontecorvi, A., \& Milardi, D. (2018). Semen proteomics reveals the impact of Enterococcus faecalis on male fertility. Protein and Peptide Letters, 25, 472-477.

Grunewald, S., Glander, H.-J., Paasch, U., \& Kratzsch, J. (2015). Age-dependent inhibin B concentration in relation to FSH and semen sample qualities: A study in 2448 men. Reproduction, 145(3), 237-244.

Hafez, M., El Dayem, S. M., El Mougy, F., Atef, A., Kandil, M., Galal, A., \& Al Hamid, A. A. (2014). The role of anti-Mullerian and inhibin B hormones in the evaluation of 46, XY disorders of sex development. Joumal of Pediatric Endocrinology and Metabolism, 27, 891-899.

Havrylyuk, A. M., Chopiak, V. V., Vlokh, N. M., Shvalikovska, R. D., \& Kurpish, M. (2013). Tsitokinova regulyatsija cholovichoy plidnoji funktsiji [Cytokine regulation of male fetal function]. Medical Aspects of Men's Health, 7, 28-38 (in Ukrainian). 
Horpynchenko, I. I., \& Romaniuk, M. H. (2016). Muzhskoye besplodie: Etiologija, patogenez, diagnostika i sovremennye metody lechenija [Male infertility: Etiology, pathogenesis, diagnosis and modern treatments]. Men's Health, 56, 8-11 (in Russian).

Horpynchenko, I. I., Nurimanov, K. R., Poroshyna, T. V., Savchenko, V. S., \& Drannik, G. N. (2016). Problemy idiopatychnoho cholovichoho besplodija [Problems of idiopathic male infertility]. Men's Health, 56, 133-137 (in Russian).

Ibrahim, E., Aballa, T. C., Roudebush, W. E., Lynne, C. M., \& Brackettet, N. L. (2015). Inhibin B is lower and anti-Müllerian hormone is similar in serum of men with spinal cord injuries compared to controls. Systems Biology in Reproductive Medicine, 61(2), 72-77.

Jungwirth, A., Diemer, T., Dohle, G., Giwercman, A., Kopa, Z., Tournaye, H., \& Rrausz, C. (2015). The updated EAU guidelines on male infertility. EAU Guidelines Office, Arnhem.

Kadyrov, Z. A., Moskvichev, D. V., \& Astahova, M. A. (2015). Prognosticheskaja znachimost' ingibina B u infertil'nykh bol'nykh (obzor literatury) [Prognostic significance of inhibin B in infertile patients (review)]. Andrology and Genital Surgery, 1, 8-15 (in Russian).

Kherraf, Z. E., Christou-Kent, M., Thomas Karaouzene, T., Amiri-Yekta, A., Martinez, G., Vargas, A. S., Lambert, E., Borel, C., Dorphin, B., Aknin-Seifer, I., Mitchell, M. J., Metzler-Guillemain, C., Escoffier, J., Nef, S., Grepillat, M. Thierry-Mieg N., Satre, V., Bailly, M., Boitrelle, F., Pernet-Gallay, K., Hennebicq, S., Fauré, J., Bottari, S. P., Coutton, C., Ray, P. F., \& Arnoult, C. (2017). SPINK2 deficiency causes infertility by inducing sperm defects in heterozygotes and azoospermia in homozygotes. EMBO Molecular Medicine, 9(8), $1132-1149$.

Krzysciak, W., Papiez, M., Bak, E., Morava, E., Krzyściak, P., Ligęzka, A., Gniadek, A., Vyhouskaya, P., \& Janeczko, J. (2020). Sperm antioxidant biomarkers and their correlation with clinical condition and lifestyle with regard to male reproductive potential. Joumal of Clinical Medicine, 9, 1785-1805.

Kulchenko, N. H., \& Demiashkin, H. A. (2016). Morfologicheskiye izmeneniya v tkani yaichka pri besplodii [Morphological changes in testicular tissue during infertility]. Andrology and Genital Surgery, 17, 45-49 (in Russian).

Kurkowska, W., Bogach, A., Janiszewska, M., Gabryś, E., Tiszler, M., Bellanti, F., Kasperczyk, S., Machoń-Grecka, A., Dobrakowski, M., \& Kasperczyk, A. (2020). Oxidative stress is associated with reduced sperm motility in normal semen. American Journal of Men's Health, 14(5), 1-8.

Kurylo, L. F., Sorokina, T. M., Matyushenko, G. N., Evdokimov, V. V., Malolina, E. A., Kovalyk, V. P., Yakovleva, V. A., Gomberg, M. A., \& Kushch, A. A (2016). Vliyaniye bessimptomnykh infektsiy urogenital'nogo trakta na pokazateli ejakuliata u muzhchin s besplodiyem i varikotsele [The effect of asympto- matic urogenital tract infections on ejaculate in men with infertility and varicocele]. Andrology and Genital Surgery, 17(2), 98-103 (in Russian).

Li, H., Chen, L. P., Yang, J., Li, M. C., Chen, R. B., Lan, R. Z., Wang, S. G., Liu, J. H., \& Wang, T. (2018). Predictive value of FSH, testicular volume, and histopathological findings for the sperm retrieval rate of microdissection TESE in nonobstructive azoospermia: A meta-analysis. Asian Journal of Andrology, 20(1), 30-36.

Li, Y., Li, Y., Zhou, N., Han, X., Ma, M., Li, L., Cai, M., Cui, Z., Lin, H., Zhou, Z., Xiong, H., \& Cao, J. (2013). Socio-psycho-behavioural factors associated with male semen quality in China: Results from 1346 heathy men in Chongqing. Journal of Family Planning and Reproductive Health Care, 39(2), 102-110.

Marchiani, S., Baccani, I., Tamburrino, L., Mattiuz, G., Nicolò, S., Bonaiuto, C., Panico, C., Vignozzi, L., Antonelli, A., Rossolini, G. M., Torcia, M., \& Baldi, E. (2021). Effects of common Gram-negative pathogens causing male genitourinary-tract infections on human sperm functions. Science Reproduction, 11(1), 20331.

Meachem, S. J., Nieschlag, E., \& Simini, M. (2001). Inhibin B in male reproduction: Pathophysiology and clinical relevance. European Journal of Endocrinology, 145(5), 561-571.

N'Guessan, M.-F., Coulibaly, P. A., Kouassi, K., \& Guillaume, Y. (2016). Lipid peroxidation and total antioxidant capacity in azoospermic semen. Annals of Medical and Diomedical Science, 2(1), 41-46.

Naher, Z., Biswas, S. K., Mollah, F. H., Ali, M., \& Arslan, M. I. (2011). Role of glutathione in male infertility. Bangladesh Journal of Medical Biochemistry, $4(2), 20-25$.

Rogozin, D. S. (2020). Muzhskaya fertil'nost': Obzor literatury oktiabria - dekabria 2019 goda [Male fertility: Reviev of the publications of October-December 2019]. Urology Herald, 8(1), 69-74 (in Russian).

Sinha, A., \& Gupta, S. (2018). Lipid peroxidation and its impact on infertility. Women's Helth and Gynecology, 4(1), 78-82.

Tchigrinets, C. V., \& Briuhin, G. V. (2018). Svyaz’ mikrobioty uretry s kachestvom eyakulyata i soderzhaniyem endokrinnykh disraptorov v semennoy zhidkosti u muzhchin [Relationship of urethral microbiota with ejaculate quality and endocrine disruptor content in seminal fluid in men]. Andrology and Genital Surgery, 19, 60-66 (in Russian).

Vorobets, M. Z., Fafula, R. V., \& Vorobets, D. Z. (2020). Suchasni pohliady na patohenez i markery azoospermiji u cholovikiv [Modem views on pathogenesis and markers of men's azoospermia]. Bulletin of Biology and Medicine, 155, 26-33 (in Ukrainian).

Yin, Y., Zhu, P., Luo, T., \& Xia, X. (2020). Association of single-nucleotide polymorphisms in antioxidant genes and their gene-gene interactions with risk of male infertility in a Chinese population. Biomedical Reports, 18, 49-54. 